\title{
Legal Protection for Creditors on Void and Null Status of the Power of Attorney to Charge Mortgage Rights
}

\author{
Piters Djajakustio $^{1} \quad$ M. Khoidin ${ }^{2} \quad$ Dyah Ochtorina Susanti ${ }^{3}$ \\ 1.Doctorate Students at Faculty of Law, Universitas Jember \\ 2.Professor and Lecturer at Faculty of Law, Universitas Jember \\ 3.Doctor and Lecturer at the faculty of Law, Universitas Jember
}

\begin{abstract}
The deed of Power of Attorney to charge Mortgage Right or known as Surat Kuasa Membebankan Hak Tanggungan (referred to as SKMHT) based on the Article 15 paragraph (3) and (4) of the Mortgage Law has a period of time, if the term is expired, the deed will be null and void by law. Then a new SKHMT is issued to replace the old Deed. The provisions regarding validity period of SKMHT harm creditors, thus a legal protection is needed. Therefore, this study further analyzed the ratio legis of void and null status, the formulation of principle of legal protection for creditors and the urgency to develop a new concept of legal protections for creditors due to the SKMHT is being void and null.
\end{abstract}

Keywords: SKMHT, void and null, creditors.

DOI: $10.7176 / \mathrm{JLPG} / 101-11$

Publication date:September $30^{\text {th }} 2020$

\section{Introduction}

The issuance of a land guarantee institution, namely the mortgage rights, has been mandated in the Article 51 of the Act Number 5 of 1960 concerning Agrarian Principles (UUPA). ${ }^{1}$ The Act Number 4 of 1996 concerning the Mortgage Rights Law (hereinafter referred to as UUHT) is to replace the provisions regarding credietverband and mortgages, as emphasized in article 29 that by the enactment of this law, the provisions regarding Credietverband as stated in staatsblad 1909-584 jo.staatsblad 1909-586 and staatsblad 1909-584 as amended by staatsblad 1937190 jo.Staatsblad 1937-191 and the provisions regarding Hypothec as stated in book II of the Indonesian Civil Code as long as it concerns the differentiation of Mortgage Rights on the right to land and land related objects are declared invalid. Based on Article 1 Number 1 of the Mortgage Rights Law (UUHT), concerning Basic Agrarian Principles, with or without the land related objects, for repayment of certain debt, which prioritize certain creditor to other creditors. ${ }^{2}$ Basically, this definition is not different from the meaning of Mortgage in Article 1162 Burgerlijke Wetboek (BW) which defines that mortgage is a material right over immovable objects to take compensation from it for the settlement of an engagement.

Basically, in granting mortgage rights, the guarantor of the mortgage must be present before the Land Deed Official (PPAT), or appointing other party to present on his behalf with the Power of Attorney to charge for Mortgage Rights (SKMHT) when he is unable to attend. UUHT does not regulate nor give opportunities to the guarantor or owner of collateral to authorize other parties to make SKMHT. ${ }^{3}$ SKMHT is a special provision that is not subject to the power of attorney regulated in BW, namely the Article 1792 to Article 1819 BW, and this provision is a specialist to generalist law regulated in BW. ${ }^{4}$ The Article 15 paragraph (2) determined that SKMHT cannot be withdrawn for any reason. This provision is reasonable to protect the creditor's interest, as the party having the power to impose mortgage rights. It also determined that the SKMHT cannot expired, unless the concerned power has been exercised or it has exceeded the expiry period of its implementation. Whereas in Article 15 paragraph (3) and paragraph (4) the UUHT limits the time period for using SKMHT. To certain credit, especially credit given to economically weak groups in the framework of government programs, can be exempted from the SKMHT time limit as stipulated in Article 15 paragraph (5) of the UUHT. The explanation in Article 15 paragraph (5) UUHT states:

In the framework of development implementation and regarding the interests of the economically weak

\footnotetext{
${ }^{1}$ Article 51 UUPA: A Mortgage Rights charged to a property rights, use rights, building use rights contained in Article 25,33, and 39 set by the Law

${ }^{2}$ See and read Article 1 Number 1 of The Act Number 4 of 1996 concerning Mortgage Rights on Land and Land Related Objects

${ }^{3}$ Elucidation of Article 15 paragraph (1) of the UUHT stated in the general explanation of number 7 , in principle, the imposition of mortgage rights must be carried out by the guarantor of the Mortgage Right. Only when it is absolutely necessary, if the guarantor of the mortgage is unable to appear before the PPAT, it is permissible to use the Power of Attorney to Charge Mortgage Rights. The power of attorney must be given directly by the guarantor of the mortgage right and should meet the requirements regarding the contents as stipulated in this paragraph. The failure to fulfill these conditions cause the power of attorney to be null and void by law, which means that the power of attorney cannot be used as the basis for drawing up a deed to grant mortgage rights. PPAT is obliged to reject the application to make APHT, if the SKMHT is not made by the guarantor of the mortgage right or does not fulfill the requirements referred to above.

${ }^{4}$ Try Widiyono. Agunan Kredit Dalam Finansial Engineering :Panduan Bagi Analisis Kredit dan Perbankan. Bogor: Ghalia Indonesia, 2009. p. 206
} 
groups, for the provision of certain loans stipulated by the Government, such as program loans, small loans, housing loans, and other similar loans, the time limit of the power of attorney to impose the mortgage rights as referred to in paragraph (3) and paragraph (4) does not apply. To determine the validity of the power of attorney to impose mortgage rights for certain types of credit is carried out by the competent Minister in the land affairs after doing consultation and coordination with the Minister of Finance, the Governor of Bank Indonesia, and other related officials.

Article 15 paragraph (6) states that the SKMHT which is not followed by a deed to grant mortgage rights within the specified time as referred to in paragraph (3) and paragraph (4), or the time determined according to the provisions as referred to in paragraph (5) is null and void. It is stated that in the elucidation of Article 15 paragraph (6), namely the provision regarding the time limit for the validity of the power of attorney to impose mortgage rights is intended to prevent the prolonged implementation of the power of attorney. This provision does not preclude the possibility of a power of attorney to impose new mortgage rights. Regarding the SKMHT described above, examining the truth of the ratio legis of the regulation is needed to be carried out, especially regarding null and void. Ratio as a notion of rationalism is a source of knowledge (truth) begun with a definite statement (axiomatic). The basic axiomatic used in constructing the system of thought is derived from clear firm and definite ideas in the human mind. Legis means having the right way of thought or in accordance with the rules of thought set out in the branch of related science. ${ }^{1}$ Thus, it needs to consider some factors or the purpose "null and void" provision as stated in Article 15 paragraph (6). Based on the description above, various problems of the SKMHT arrangement regarding legal protection for creditors, namely:

a. Philosophical Problem

The regulation of the SKMHT time span as stipulated by the UUHT Article 15 paragraph (3), (4), is disharmony to the 1945 Constitution of the Republic of Indonesia Article 28 D (1) which mandates the right of everyone to recognition, guarantee, protection and fair legal certainty and equal treatment before the law, including the rights of people as creditors. Furthermore, the losses accept by creditors as a result of the SKMHT regulation basically distorted the function of creditors as an important and fundamental component for national economic development.

b. Juridical Problem

The period of SKMHT as stipulated in the UUHT Article 15 paragraph (3), (4) does not reflect the concept of legal objectives which should provide justice and expediency within the framework of protecting creditors, as well as it is not in accordance with the creditors prudential principle.

c. Theoretical Problem

The regulation on the period of SKMHT as stipulated in the UUHT Article 15 paragraph (3), (4) indicates the lack of legal protection for creditors since this regulation tend to cause creditors to no longer own a collateral for repayment of their debts.

d. Sociological Problem

The regulation on the period of SKMHT as stipulated in the UUHT Article 15 paragraph (3), (4) can cause bad credit that may be detrimental to creditors.

Further research needs to be executed to answer these problems. This study focuses on the Ratio Legis of SKMHT Null and Void Status, the Formulation of Legal Protection Principles for Creditors Due to the SKMHT Null and Void occurrence, and Urgency to Build a New Concept of Legal Protection for Creditors Due to the SKMHT which is Null and Void.

\section{Research Method}

The juridical normative method is used in this study. This method conducted a research by reviewing and analyzing the substance of the laws and regulations on the subject matter ${ }^{2}$ or legal issues in its consistency with existing legal principles. By this method, a comprehensive study and analysis is expected to be carried out to obtain scientific legal prescriptions with the highest accuracy of legal issues to find, first, the ratio legis of SKMHT annulment status without the making of APHT due to its expired period that contradicts the principle of legal protection for creditors; second, the legal principles used to provide legal protection for creditors due to the causes of the SKMHT legal cancellation which is not followed by the making of APHT due to its expired period; third, construction of future regulations in order that the legal nullification status of SKMHT without the making of APHT can provide legal protection for creditors. The problem approaches used are: historical approach, conceptual approach, case approach, statute approach, and comparative approach

\footnotetext{
${ }^{1}$ Suteki dan Galang Taufani. Metodologi Penelitian Hukum (Filsafat, Teori dan Praktik). Depok: RajaGrafindo Persada, 2018. P. 129

${ }^{2}$ Peter Mahmud Marzuki, Penelitian Hukum, Jakarta: Prenada Media, 2005. P. 29 -36
} 


\section{Results and Discussion}

\subsection{Ratio Legis of Null and Void Status of the SKMHT}

The Collateral institutions including mortgage rights are to guarantee the repayment of certain debts. Thus the creditor believe that the debtor will perform the achievements in accordance with the agreement made by the partiesk. ${ }^{1}$ Based on the principle of consensualism as adhered to by agreement law in Indonesia, the contract was born when an agreement made between the parties in a contract. Thus, an agreement should fulfill the first conditions of Article $1320 \mathrm{BW}$, namely the parties involved agreed to bind themselves, while the validity of the agreement should fulfill the four conditions contained in Article $1320 \mathrm{BW} .{ }^{2}$ Credit collaterals are anything that has cash value tied to an agreement as collateral to secure repayment of a loan based on a credit agreement made by creditors and debtors. The juridical function of collateral is to serve a protection for creditor security, namely assurance of debtor's loan repayment or the implementation of an achievement by the debtor or by the debtor guarantor. ${ }^{3}$ A legal protection of SKMHT is to protect creditors and debtors for signing a credit agreement with a land rights collateral. The juridical function of collateral is a means of legal protection for the security of creditors for their debts repayment or an achievement of the debtor or by the debtor guarantor. ${ }^{4}$ Definitively, the SKMHT is a power of attorney given by a guarantor to another party to charge a mortgage by signing the APHT. It was made because the APHT was not able to be made / signed for certain reasons. Thus, the SKMHT is used when a time conformity determined by the Bank / Creditors occur in the future to represent the guarantor to impose mortgage rights by signing the APHT. ${ }^{5}$

The article 15 of the UUHT stipulates the period of SKMHT i.e., 1 (one) month for registered land rights and 3 (three) months for unregistered land rights, but these provisions do not apply to certain types of credit as stipulated in the Regulation of the State Minister for Agrarian Affairs / Head of BPN number 4 of $1996 .^{6}$ The regulation regulates that to certain types of credit, SKMHT is valid until the end of the credit agreement. It shows the government's attention in providing protection for economically weak people who need credit, especially in the case of housing loans. Indeed, it is to improve communities' welfare and create justice, with the hope of achieving social welfare and prosperity for the entire Indonesian people as one of Indonesia's National goals. ${ }^{7}$ Meanwhile, in principle, the imposition of Mortgage Rights must be carried out by the grantor of the Mortgage, and if the lender of the Mortgage is unable to attend before the PPAT, he is obliged to appoint another party, in this case the Creditors, to present on his behalf. Granting power of attorney is a legal action originated from an agreement carried out in everyday life. For various reasons, due to some complex activities as member of society, granting power is often carried out by giving power of attorney.

According to $\mathrm{BW}$, the granting of power can act as a general power and / or as a special power of attorney. The power given in general includes management actions which cover all the interests of the grantor. Whereas a special power of attorney only concerns on one or more specific interests, therefore it is necessary to grant power of attorney stating everything clearly. The act of imposing rights over immovable property such as hypothec or mortgage, can only be done by the owner. One of the special powers to impose Mortgage Rights as regulated in the UUHT is known as SKMHT. The UUHT expressly states that SKMHT cannot be withdrawn or cannot be terminated for any reason except the power has been exercised or the period has expired. The period of the Power of Attorney to charge Mortgage Rights as regulated in the Mortgage Rights Law in Article 15 paragraphs (3) and (4) is 1 (one) month for registered land and 3 (three) months for unregistered land. If it is not completed with a deed of charging mortgage, then it will be null and void by law.

The SKMHT is Void and Null by law since the deadline of SKMHT to be followed up into APHT, i.e., one month for the registered land, and three months for unregistered land is not fulfilled or is violated. It is very detrimental to creditors considering that the bank in its credit agreement explicitly states the land to be guaranteed and given SKMHT, but the mortgage rights cannot be imposed due to the expiry period of the SKMHT. ${ }^{8}$ Meanwhile, the SKMHT period which is not based on merit or agreement can be made for certain credits and is not a null and void condition of the SKMHT. In fact, the stipulation of a short period of time can endanger the interests of creditors, because some cases have shown such circumstances, that credit has become bad even though it has only been given within 3 (three) months. This bad credits does not occur due to the bank's analysis on the feasibility of the business to receive credit, but it can occur due to the economic conditions or changes in

\footnotetext{
${ }^{1}$ Siti Malikhatun Badriyah, "Perlindungan Hukum Bagi Kreditor dalam Penggunaan Base Transceifer Station (Bts) sebagai Objek Jaminan Fidusia dalam Perjanjian Kredit," Media Hukum, Vol. 22, No. 2, 2016, P. 16.

${ }^{2}$ Ibid., P. 17.

${ }^{3}$ Herlien Budiono, Op. Cit., P. 81

${ }^{4}$ Paulus Tiku Taru Padang dan Olivia Maria Dotulong, Op. Cit., P. 12

${ }^{5}$ Siti Malikhatun Badriyah dkk., Op.Cit., 27.

${ }^{6}$ Miftahul Jannah, Op.Cit., 36.

${ }^{7}$ Paulus Tiku Taru Padang dan Olivia Maria Dotulong, Op.Cit., 4.

${ }^{8}$ Ferry Assaad, Anwar Borahima, dan Nurfaidah Said, "Kekuatan Hukum Surat Kuasa Membebankan Hak Tanggungan (SKMHT) Sebagai Dasar Pembebanan Hak Tanggungan Dalam Perjanjian Kredit."
} 
regulations. ${ }^{1}$ However, to follow up the SKMHT to APHT for Mortgage Rights registration at the local National Land Agency is constrained by the prolonged process at the National Land Agency. So that the Creditors will resign the SKMHT II (new) to continue the expired SKMHT I (First). There are several steps to sign the second SKMHT (new), i.e., the new SKMHT is signed before the period of the first SKMH ends, the new SKMHT is taken at the time the first SKMHT expires, and the new SKMHT is signed after the first SKMHT expired. ${ }^{2} 1$ (one) month period of registered SKMHT is needed because at the time the credit is given, the collateral is still at the process of document transferring or it is still at another Bank since the credit is given in a Take Over process. A 3 (three) months period of this SKMHT is for unregistered collateral (certificate process). The period is based on the credit tenor given by the bank. This SKMHT applies to certain credit ceilings according to the bank's internal rules.

The legal consequences of the SKMHT issuance cannot be separated from the validity period the SKMHT, because if SKMHT is changed to APHT he legal consequences are the nature and provisions adhered to APHT, including the executorial nature. If the SKMHT is valid for a credit period, then the legal consequence will be like other Power of Attorney, namely the transfer of all things authorized to the power of attorney, including if it is later upgraded to APHT. For example, Mortgage Rights (SKMHT) for certain credits do not have to be upgraded to APHT and remain valid until the expiration of the credit contract. This point distinguishes the provisions of SKMHT in general, that if SKMHT is not upgraded to APHT within a certain time, it becomes null and void by law. ${ }^{3}$

\subsection{The Formulation of Legal Protection Principles for Creditors Due to the Null and Void Status of SKMHT}

The important role of collateral is to give rights and powers to the bank as the lender (creditor) to get repayment with collateral if the borrower (debitor) fails to repay the debt at the time specified in the agreement. ${ }^{4}$ A Material guarantee has the most important and strategic position in bank credit. The most requested material collateral by banking institutions is in the form of land, because economically, land has a more favorable prospect. Automatically, land is considered to be the most effective and safe guarantee by the Banks with Mortgage Rights. ${ }^{5}$ In brief referring to Civil Law in Indonesia, creditors are divided into several types based on special privileges they have. The provisions related to the existence of such privileges are regulated in Articles 1131, 1132 and 1134 BW $^{6}$ Based on these three Articles, the position of creditors according to civil law can be classified into 3 types. $^{7}$ First, it is an unsecured creditor, namely creditors who must share and compete with other creditors proportionately (on a pari passu basis). Second, it is a Preferred Creditor who has the privilege of being prioritized either because it is granted by the law or due to a guarantee. ${ }^{8}$ Third, it is a Separatist Creditor, namely a creditor who has the privilege of being prioritized over the material guarantee he receives. He is also referred to as a separatist creditor because he has separate rights from other creditors due to his debts are guaranteed by material rights (such as Pawning, Fiduciary and Mortgage). ${ }^{9}$

Based on a study in the Collateral Legal System, the privileges of mortgage holders as separatist creditors have been more specifically regulated in the UUHT, namely in Article 1 number 1 of UUHT (related to the definition of Mortgage Rights), Article 6, 14 paragraph (1)-(3), and Article 20 paragraph (1)-(3) of UUHT (related to Parate Executie or auction on its own power), and Article 21 of UUHT. ${ }^{10}$ Thus, it is clear that creditors owning SKMHT, according to the Collateral Legal System will only have the status of concurrent creditors having no privilege as stated in Article 1132 BW. In accordance with the provisions in Article 1 number (5), Article 10, Article 13 and Article 14 of the UUHT stating that the collateral right in the form of Mortgage will only be obtained by a creditor after the SKMHT is continued with the Granting of Mortgage Rights and Registration of Mortgage Rights until the issuance of the Land Book/Certificate of Mortgage Rights. ${ }^{11}$ Since the creditors as SKMHT holders do not have a Mortgage certificate who do not only provide guarantee rights but also as a Groose Acte having executive power, thus the creditors cannot perform parate executie and can only file a civil suit to the court when

\footnotetext{
${ }^{1}$ Muhammad Iqbal, "Kajian Yuridis Terhadap Surat Kuasa Membebankan Hak Tanggungan Kedua (II) Dan Berikutnya Sebagai Perpanjangan Surat Kuasa Membebankan Hak Tanggungan Pertama (I) Yang Telah Berakhir Jangka Waktu.”

${ }^{2}$ I Putu Deny Wiryanta, I Ketut Mertha, dan I Made Puryatma, Op.Cit., 39.

${ }^{3}$ Fuat Rifai, Lucky Endrawati, Abdul Madjid, Analisis Yuridis Terhadap Ketentuan Surat Kuasa Membebankan Hak Tanggungan (SKMHT) Kredit Tertentu Sebagai Upaya Mewujudkan Keseimbangan Perlindungan Hukum Bagi Kreditur (BANK), Postgraduatea Program, Faculty of Law, Universitas Brawijaya.

${ }^{4}$ Ibid., P. 5.

${ }^{5}$ Peris Maha dan M Kn, above note 186, P. 5.

${ }^{6}$ Hadi Wijaya, Op.Cit., 22, P. 4.

${ }^{7}$ Disusun Oleh, above note 188 , P. 12

${ }^{8}$ Dhevi Nayasari Sastradinata, Op.Cit., 85, P. 6.

${ }^{9}$ Hadi Saputro Widjaja, Op.Cit., 34, P. 8.

${ }^{10}$ Ayang Fristia Maulana, Op.Cit., 48, P. 14.

${ }^{11}$ Ibid., P. 8.
} 
the debtor is in default. ${ }^{1}$ The Article $1320 \mathrm{BW}$ stipulates that the validity of agreements need four conditions, namely: An agreement of Those who Bind themselves, the ability to make agreements, a certain thing and lawful causes. The principle of freedom of contract is one of the very important matters in contract law. ${ }^{2}$ This freedom, by some law scholars, is usually based on Article 1338 paragraph (1) BW that all legal agreements act as law for those who make them as well as based on Article 1320 BW which explains the validity of the agreement. ${ }^{3}$

The credit agreement is one of contracts that must fulfill these four elements. Banks as creditors and customers as debtors must first make a credit agreement before making credit disbursements. The term credit agreement was first put forward in the Banking Law of 1967 article 1c instructions of Cabinet Presidium Number 15/EK/ 10/1966 number I point 5 on Policy Guidelines in the Credit Sector stated that credit is the supply of money or claims based on a loan agreement between the bank and another party in which the borrower is obliged to repay the debt after a certain period of time. with a predetermined amount of interest. ${ }^{4}$ In fact, the position of the collateral agreement, which is constructed as an accessoir agreement, guarantees the strength of the collateral institution for the security of credit distribution by creditors. ${ }^{5}$ An accessoir agreement has legal consequences as well as other accessoir agreements. In making a credit agreement, banks generally will not give credit without considering the collateral given by the debtor to guarantee the loans they receive. ${ }^{6}$ As long as debtors have good performance in the credit agreement guaranteed by the Mortgage Right, then the mortgage right as a guarantee right does not function properly. The Mortgage rights will be used if the debtor is in default. When a mortgage grantor cannot appear before a Notary or PPAT, Article 15 of the UUHT provides an opportunity for the mortgage provider to with an authentic power of attorney to impose mortgage rights that meets the requirements. ${ }^{7}$

Based on Article 15 paragraph (1) letter a, what is meant by does not contain the power to carry out other legal actions, for example does not contain the power to sell, lease objects of Mortgage Rights, or extend land rights, so that in particular the SKMHT is made only to contain the power of attorney to only imposes Mortgage Rights, thus it is separated from other deeds. ${ }^{8}$ In this case, the UUHT expressly states that the SKMHT cannot be withdrawn or cannot be terminated for any reason except because the power has been exercised or its term has expired. The period of the Power of Attorney to Charge Mortgage Rights as regulated in the Mortgage Rights Law in Article 15 paragraphs (3) and (4) is 1 (one) month for registered land and 3 (three) months for unregistered land. If it is not followed by making a deed, the imposing mortgage rights will be null and void by law. ${ }^{9}$

The SKMHT is Void and Null by law since the deadline of SKMHT to be followed up into APHT, i.e., one month for the registered land, and three months for unregistered land is not fulfilled or is violated. It is very detrimental to creditors considering that the bank in its credit agreement explicitly states the land to be guaranteed and given SKMHT, but the mortgage rights cannot be imposed due to the expiry period of the SKMHT. ${ }^{10}$ Meanwhile, the SKMHT period which is not based on merit or agreement can be made for certain credits and is not a null and void condition of the SKMHT. In regards to the reformulation of the legal protection principle of creditors regarding the nullification of SKMHT, the mechanism for granting mortgage rights in SKMHT is the key of transferring process to the third parties, because it includes certain credit guarantees. It is regulated in Article 10 paragraph (2) of the UUHT which states: "Imposing mortgage rights is preceded by a promise to provide security rights as certain repayment guarantees, which are contained in and are inseparable parts of the debt agreement or other agreements that cause the debt. Elucidation of Article 15 paragraph (1) UUHT Granting mortgage rights is carried out by making APHT by PPAT in accordance with the prevailing laws and regulations.

Meanwhile, the juridical obstacles in making SKMHT by notaries or PPAT were not found, because the regulations of SKMHT have been clearly regulated in the UUHT. However, these obstacles are found in the administrative management, i.e., in the process of using SKMHT to APHT. The problems encountered include non-compliance on the provisions of Government Regulation No. 13/2010 concerning Types and Rates of NonTax State Revenues Applicable to the National Defense Agency. ${ }^{11}$ Therefore, basically SKMHT secured by UUHT on land and land related objects cannot be used as a basis for executing the collateral. In order to execute the guarantee, the SKMHT must first be registered and followed up with the making of APHT , and to issue mortgage right certificate which has permanent executorial power and legal force. To obtain a mortgage certificate, SKMHT

\footnotetext{
${ }^{1}$ Ibid., P. 4.

${ }^{2}$ Muhammad Iqbal, Op.Cit., 53, P. 4.

${ }^{3}$ Ahmad Zulfikar, Op.Cit., 20, P. 6.

${ }^{4}$ Agung Cahyo Kuncoro, above note 194, P. 16.

${ }^{5}$ Hadi Saputro Widjaja, Op.Cit., 34, P. 20.

${ }^{6}$ Inche D P Sayuna, Op.Cit., 5, P. 18.

${ }^{7}$ Anisa Kartika Sari, "Perlindungan Hukum Terhadap Kreditur Pemegang Hak Tanggungan Yang Tidak Didaftarkan Di Kantor Pertanahan," P. 13, pada P. 14.

${ }^{8}$ Anisa Kartika Sari, Op.Cit., 40

${ }^{9}$ Fani Martiawan Kumara Putra, above note 64

${ }^{10}$ Ferry Assaad, Anwar Borahima, dan Nurfaidah Said, Op.Cit., 42.

${ }^{11}$ I Putu Deny Wiryanta, I Ketut Mertha, dan I Made Puryatma, Op.Cit., 38.
} 
registration should not exceed the time limit set by the UUHT, so that SKMHT will not be null and void by law and the manifestation of legal protection principle for creditors can be applied completely. ${ }^{1}$

\subsection{The Urgency To Develop The Concept Of Legal Protection For Creditors As A Result Of A Power Of Attorney To Impose A Mortgage Which Is Null And Void}

An essential element in granting credit is the trust of the bank as a creditor to the borrower as a debitor based on the loan agreement. Trust is the basis of any agreement which contains these elements namely, two parties, a loan agreement, trust, achievement, reward and a certain period of time. From a juridical perspective, the relationship between debtors and banks or creditors consists of two forms, namely contractual relationships and non-contractual relationships. The main relationship between a bank or creditors and debtors is a contractual relationship. The relationship is based on a contract made between the bank as a creditor and the debtor. ${ }^{2}$ This relationship stems from the provisions of Book III of the Civil Code. In principle, the legal relationship between banks or creditors and debtors is a fiduciary relationship, a confidential relationship and a prudential relationship. The Credit Agreement will contain provisions for the maximum amount of credit, how to withdraw credit and other important terms, such as the provisions on collateral for credit. Hartono Hadisoeprapto argues that a collateral is something given to creditors to assure that debtor will fulfill the obligation arising from an engagement. Loan agreements between creditors in this case the bank and the borrower or debtor are bound by collateral rights. ${ }^{3}$ The creditor and the debtor make a promise by binding certain objects or the ability of the debtor, with the aim of providing security and legal certainty for credit repayment or implementation of the collateral principle agreement. The binding of credit collateral objects and the mortgage rights is carried out when a debtor obtains credit from a bank, making immovable property in the form of land (land rights) with or without land related objects, (for example buildings, plants, statues, etc.) as collateral without transferring the collateral physically to the creditor or bank.

The collateral is still physically owned by the debtor or the owner of land rights, however since it is used as collateral for a debt with a mortgage agreement, the authority of the guarantor to carry out legal actions with third parties or other actions decreasing the value of the collateral is limited to the security rights owned by creditors as holders of mortgage rights. In the practice of granting mortgage rights preceded by SKMHT, the process takes a long time since the certificate of land rights as credit's collateral cannot be completely tied to the APHT, it is due to the administrative processes carried out at the land office such as the Roya process, splitting, separation, merger, replacement Blank, Transfer of Rights (Transfer of Certificate Name), and changes to land rights which take a long time so that the period expires and the APHT has not been made. A legal construction related to the enforcement of SKMHT is needed. Since the period determined by the UUHT is relatively short, a Notary or PPAT should maximize the SKMHT process to not exceed the expiry period. When the land certificate process has not been completed, the SKMHT is possibly signed several times before the APHT can be signed. After all the requirements to sign APHT have been fulfilled, then the APHT is ready to be signed by the creditor. ${ }^{4}$ To prevent the prolonged process of granting power of attorney to achieve legal certainty, the SKMHT must have a time limit. Since the requirements regarding the time period are not fulfilled, the SKMHT will become null and void by law as regulated in Article 15 Paragraph (4) of the UUHT. It implies that granting power of attorney should be seriously carried out to obtain legal certainty both for the holder and the grantor of mortgage.

On the other hand, the imposition of mortgage rights preceded by the provision of SKMHT also has several weaknesses, including the period of SKMHT to be followed up into APHT before issuing a Certificate of Mortgage Rights. If the creditors do not immediately follow up the making of APHT, according to the SKMHT period, then the SKMHT will be null and void by law. Nullification of SKMHT causes the bank or collateral holder to be unable to register security rights over objects of land rights taken as collateral or credit guarantees. As a consequence, the bank or creditors or the last party holding credit collateral cannot execute according to the provisions of Article 6 junto Article 14 Paragraph (1), (2) and (3) and Article 20 (1) and (2) of UUHT. By the cancellation of the SKMHT, it is possible to issue a new SKMHT as long as the mortgage provider is willing to sign the new SKMHT. If the guarantor of the mortgage is not willing to sign a new SKMHT. Therefore, it will be difficult for the creditors to impose mortgage rights in the future if the they lose their preference right over the object of the security right. The implication of the SKMHT expiry period of a credit agreement is when the debtor defaults. Thus, the creditor's position becomes a concurrent creditor. To submit a new credit, they can file a default claim to the district court based on the credit agreement made between the debtor and creditor signed at the time of the credit agreement. The inhibiting factors in the process of upgrading the SKMHT to APHT are expensive costs and short time period. To overcome these obstacles, to renew expired SKMHT accordance with statutory regulations and to follow up SKMHT to become APHT should be carried out. The administrative problems

\footnotetext{
${ }^{1}$ Miftahul Jannah, above note 63.

${ }^{2}$ Novy Dyah Rahmanti, Op.Cit., 135, P. 17.

${ }^{3}$ Effendi Perangin-Angin, Op.Cit., 161, P. 134.

${ }^{4}$ Perangin-angin Effendi, Op.Cit., 141, P. 194.
} 
occurring on the process of using SKMHT to become APHT include non-compliance with the provisions of Government Regulation Number 145 of 2015 concerning Types and Rates of Non-Tax State Revenues Applicable to the National Defense Agency. ${ }^{1}$

The bank as the creditor and holder of the mortgage will immediately issue a warning letter to the Notary and/or the PPAT who has the task of processing the guarantee binding and completing it, and they must prepare a cover note regarding SKMHT extension to complete the process of granting mortgage rights over land and immediately register the mortgage rights at the local land office to issue a certificate of mortgage. Regarding certain credit guarantees of the SKMHT function, the law confirms that it does not provide new rules regarding the repayment of credit of a collateral or executorial rights for a guarantee at a bank. The law accommodate people to avoid excessive fees of applying a credit at a bank. Thus, the credit agreement tied to SKMHT and not followed by APHT due to the debtor's default, makes the mortgage right does not exist and the bank or creditor cannot execute the mortgage right. Implications of the SKMHT term expiration in the credit agreement if the debtor is in default, the creditor is not considered a preferred creditor or creditors who can be prioritized if the SKMHT has not been followed by APHT to register its mortgage rights at the land office.

Creditors are not able to execute collateral, but they can file a lawsuit to the court. In the material juridical views, collateral functions as a preventive measure for debt repayment. There are two forms of preventive legal protections (prevention) for creditors in terms of granting new guarantees until SKMHT is made, namely conducting discussion with debtors, making new SKMHT by inviting the debtor to attend before the Notary/PPAT to sign the SKMHT, while repressive legal protection (coercion) can be carried out by creditor by filing a lawsuit against the defaulting debtor at the District Court. If the SKMHT has not been followed by the signing the APHT, thus the creditor only serves as a concurrent creditor. Creditors are expected to provide credit to debtors whose collateral commitment is preceded by signing the SKMHT. The bank should release half of the funds loaned first and the rest is given after the collateral is binding to the bank. It is aimed to protect the Banks security in providing loans to debtors. A signed SKMHT should be followed by the signing of the APHT to immediately register the mortgage rights at the land office to issue a Certificate of Mortgage to provide protection to creditors. If the debtor defaults, the creditor can execute the collateral object. ${ }^{2}$ The Land Office is expected to work faster and make better and faster changes in serving the community.

It is expected that the Article 15 paragraph (1) UUHT No.4 of 1996 clearly stipulated that SKMHT made with a Notary deed is subject to Article 38 UUJN Number 30 of 2004, and SKMHT made with a PPAT deed is subject to Article 96 paragraph (1) Regulation of the Head of the National Land Agency (hereinafter referred to as Perkaban) Number 8 of 2012, and the Notary/PPAT is expected to be decisive in implementing the provisions of Article 15 paragraph (1). In practice, the position of SKMHT made with a Notary deed based on Article 96 paragraph (1) is incorrect, SKMHT made with a Notary deed is regulated in Article 38 UUJN to fulfill the criteria as a Notary deed. The National Land Agency of the Republic of Indonesia (BPNRI) need to review the provisions in Article 96 paragraph (5) so that the implementation of registration of Mortgage Rights at the Land Office regarding SKMHT made with a Notary deed based on Article 38 UUJN No. 4 of 2004 is acceptable. The National Land Agency of the Republic of Indonesia (BPNRI) should consider the general provisions for making authentic deeds before making PPAT authentic deed regulations because based on Article 1888 of the Civil Code states that the power of written evidence is on the authentic deed, SKMHT based on Article 96 paragraph (1) The Perkaban is not clearly determined which is the original Deed. In Article 1868 of the Civil Code regarding the provisions of an authentic deed. The SKMHT made with a Notary deed based on Article 96 paragraph (1) of the Perkaban has violated the provisions of an authentic deed, where the deed is made in the form determined by unclear laws and regulations due to different views on the SKMHT regulation, namely between Article 96 paragraph (1) Perkaban and Article 38 of the UUJN. ${ }^{3}$ Thus, the creditors are expected to minimize the use of SKMHT by maximizing the direct signing of the APHT, If the land/object of the Mortgage is outside the working area of the Notary/PPAT, then it is obliged to use the services of a Notary/PPAT where the land/object of the Mortgage is located in order to avoid different views on the arrangement of the SKMHT Deed.

Banking institutions plays an important role in achieving national development goals. Indonesia banking institutions are expected to have efficient, healthy, natural, and competitive performance, capable of protecting funds entrusted by the community, and are capable of channeling these public funds into productive fields for the achievement of development targets. ${ }^{4}$ As an effort to support the sustainability and improvement of development, banking institutions have shown rapid development in line with the progress of Indonesian and International economic development, and in line with the increasing demands of the public for banking services. ${ }^{5}$ Each provision

\footnotetext{
${ }^{1}$ Effendi Perangin-angin, Op.Cit., 155, P. 217.

${ }^{2}$ Irsyad Lubis, 2010, Bank dan Lembaga Keuangan, USUpress, P. 165.

${ }^{3}$ Herlien Budiono, Op.Cit., 1, P. 86.

${ }^{4}$ Permadi Gandapraja, 2004, Dasar dan Prinsip Pengawasan Bank, Gramedia Pustaka Utama, P. 65.

${ }^{5}$ Abdul Rokhim dan MH SH, "Hak Informasi atas Kesehatan Bank,” Jurnal Negara dan Keadilan, Vol. 6, No. 10, P. 12.
} 
made for the banking industry will ultimately lead to one goal, namely to produce a healthy, strong and stable banking system aiming that the banking sector can play an important role in supporting national development. Thus, the community through micro, small and medium enterprises, who needs financial assistance for their business capital is facilitated by the presence of banks. By the movement of the people's economy in the real sector, it will automatically accelerates the national development. The construction of physical facilities and infrastructure for the public was also helped by the availability of fresh funds through banking ${ }^{1}$ Contractors, both public and private, who need funds to work on development projects can apply for credits to banks. Thus, banks have a very important and strategic role in supporting national economic development. ${ }^{2}$ The Bank's healthy conditions is defined as a bank's ability to carry out normal banking operations and ability to fulfill all its obligations properly based on applicable banking regulations. This definition has a broad limitation because the soundness of a bank includes the condition of a bank to carry out all its banking business activities. These activities include: ${ }^{3}$

a. Ability to collect society's fund and other institutions, and its own capital;

b. Ability to manage funds;

c. Ability to distribute funds to the community;

d. Ability to fulfill its obligations to society, employees, owners of capital, and other parties;

e. Compliance to applicable banking regulations.

The financial and non-financial condition of a bank based on sharia principles is in the interest of all related parties, including the owner, manager (management) of the bank, the community using bank services, Bank Indonesia as the bank supervisory authority or other parties. The conditions of the bank used by these parties to evaluate the performance of the bank in applying the principles of prudence, compliance of sharia principles, compliance of applicable regulations, and risk management. ${ }^{4}$ Like human health, banking soundness must always be assessed for excellent performance in serving customers. The bank's health can be assessed from several points of view, this assessment aims to determine whether the bank is healthy, healthy enough, or unhealthy. Therefore, Bank Indonesia as the supervisor of the banks can provide direction or approval on how the bank operation must be carried out or even stopped. ${ }^{5}$

This assessment aims to determine whether the bank is in a healthy, healthy enough, or unhealthy condition. For a healthy bank, it is necessary to maintain its soundness, while the unhealthy banks need to immediately recover. Bank Indonesia as the supervisor of the banks can provide direction or approval on how its operation must be carried out or even stopped. The standards for conducting bank health assessments have been determined by the government through Bank Indonesia. Banks are required to make regular or periodic reports of all their activities in a certain period. ${ }^{6}$ This report is studied and analyzed to see the condition of a bank. In each assessment, the condition of a bank is determined. The banks that have been assessed previously, can also be re-assessed to see whether they have increase or decrease in their health. Each bank is expected to continue to improve. However, if a bank continues to be unhealthy, it must be warned or is given sanctions based on the applicable regulations. Bank Indonesia, as the supervisor of the banking sector may suggest to make various improvements.

The improvements made include management changes, mergers, consolidations, acquisitions or even liquidation (dissolution) if the bank's condition is in extremely bad condition. This consideration is dependent on the conditions experienced by the bank concerned. If the bank's condition is bad, but it still has some potential, then a solution is seek by doing business merger with other banks. Meanwhile, the liquidation step is the last solution to save public fund. ${ }^{7}$ Development is a series of continuous improvement covering all interests of the people, nation and state to realize the national goals set out in the Preamble of the 1945 Constitution of the Republic of Indonesia, namely protecting the entire nation and Indonesian people, advancing public welfare, educating people, and implementing world order based on freedom, eternal peace and social justice. The whole spirit, direction and movement of development are carried out as the practice of the principles of Pancasila and as a complete unity, which includes the practice of the first principle, namely the Believe in One God, i.e., the common responsibility of all religious groups and belief in God Almighty to uphold a strong spiritual, moral and ethical foundation for national development as the practice of Pancasila. ${ }^{8}$

The practice of a just and civilized humanity principle include enhancing the dignity and human rights and obligations of citizens as well as the elimination of occupation, misery and injustice on the earth. Practicing the principle of unity of Indonesia includes enhancing the development of the nation in all aspects of human life,

\footnotetext{
${ }^{1}$ Ikatan Bankir Indonesia, 2016, Manajemen Kesehatan Bank Berbasis Risiko, Gramedia Pustaka Utama, P. 13.

${ }^{2}$ Irfan Syauqi Beik, Op. Cit., P. 10.

${ }^{3}$ Chandra Utama, "Mengukur tingkat kesehatan bank di Indonesia," Bina Ekonomi, Vol. 10, No. 1, 2006 , P. 17.

${ }^{4}$ Iwan Triyuwono, Op. Cit., P. 4.

${ }^{5}$ Thamrin Abdullah, Op. Cit., P. 7.

${ }^{6}$ Irsyad Lubis, Op. Cit., P. 141

${ }^{7}$ Irsyad Lubis, Op. Cit., P. 185

${ }^{8}$ M. Dawam Rahardjo, "Evaluasi dan Dampak Amandemen UUD 1945 terhadap Perekonomian di Indonesia,” UNISIA, No. 49, 2016, P. 19.
} 
society, nation and state so that the sense of solidarity is getting stronger to strengthen national unity and integrity. ${ }^{1}$ The practice of the principle of democracy guided by the inner wisdom in the unanimity arising out of deliberations amongst representatives includes efforts to further grow and develop Pancasila democratic political system which is increasingly capable of maintaining dynamic national stability, developing awareness and political responsibility of citizens, and stimulating the people in the political process. ${ }^{2}$ The practice of the principle of social justice for all Indonesian people includes efforts to develop high economic growth associated with equitable development which leads to prosperity for all Indonesian people in an economic system as a mutual effort based on principle of kinship. National development is carried out in a planned, comprehensive, integrated, directed, gradual, and continuous manner to push the improvement of national capacity in the context of realizing a an equal life to other developed nations. ${ }^{3}$

National development is the development of, by and for the people, carried out in all aspects of the life of the nation, which includes political, economic, socio-cultural, and defense and security aspects, which is the embodiment of the archipelago/Nusantara insight, and to strengthen national defense carried out by building the development fields adjusted to a long-term goals. ${ }^{4}$ National development is a reflection of the will to continuously improve the welfare and prosperity of the Indonesian people in a just and equitable manner, as well as to develop people's lives and the administration of an advanced and democratic country based on Pancasila. National development is aimed at realizing a just and prosperous society based on Pancasila and the 1945 Constitution within the Unitary State of the Republic of Indonesia which is independent, sovereign, and untied in an atmosphere of a safe, peaceful, orderly and national life, and dynamic in a free, friendly, orderly, and peaceful world environment. The national development is a continuous development to realize a just and prosperous society based on Pancasila and the 1945 Constitution.

To achieve the goals, the development should consider the conformity, harmony and balance of various elements of development, including in the economic and financial fields. Today, the national economy development shows an increasingly integrated direction with the regional and international economies that can support the national economy. One sector that is able to rapidly develop and can support the national economy as well as to play a major role in national development is the banking sector. ${ }^{5}$ The baking sector has a crucial function for a country's economy. Therefore, the bank assets in the form of public trust is important to maintain in order to increase the efficiency of bank use and the efficiency of intermediation, and to prevent bank runs and panics. Public trust is also needed because banks do not have sufficient cash to pay obligations to all their customers at once. The banking industry in Indonesia has experienced some problems which the root causes are the lack and the absence of good corporate governance.

\section{Conclusions}

Regarding the above elaboration, it is concluded that:

1. The ratio legis of null and void by law status of power of attorney imposing mortgage rights is an effort to protect the public interest. A nullification shows an action which does not cause legal consequences as intended and it occurs automatically without requiring an act of cancellation or is often called null and void. Such legal consequences are usually given when a public interest involved in it. The existence of the sanction "null and void" on the power of attorney to charge a mortgage right regulated in Article 15 of the UUHT is to protect the public interest. Article 15 paragraph (1) regulates the provisions of the fulfillment of the requirements on the content of the power of attorney to impose mortgage right to guarantee legal certainty for the power of attorney, while the validity period as stated in Article 15 paragraph (3) and (4) are intended to prevent it from any delay in exercising the power of attorney.

2. The formulation of the principle of legal protection for creditors due to a legal nullification of the SKMHT is the mechanism of granting security rights in the power of attorney to charge mortgage rights because it contains certain credit collateral. It is regulated in Article 10 paragraph (2) of the UUHT which states: "Imposing mortgage rights is preceded by a promise to provide security rights as certain repayment guarantees, which are contained in and are inseparable parts of the debt agreement or other agreements that cause the debt. In addition, the provisions of article $1338 \mathrm{BW}$ actually stipulate that an agreement is legally binding both parties as a law. It is clear that, the position of the creditor related to null and void by law of the SKMHT received a guarantee as determined by article $1131 \mathrm{BW}$. However, this collateral is general and does not provide certain position for creditors.

\footnotetext{
${ }^{1}$ Renniwaty Siringoringo, Op. Cit., P. 14.

${ }^{2}$ Taufiqurrohman Syahuri, "Politik Hukum Perekonomian Berdasarkan Pasal 33 UUD 1945," Jurnal Konstitusi, Vol. 9, No. 2, 2016 , P. 243.

${ }^{3}$ Elli Ruslina, "Makna Pasal 33 Undang-Undang Dasar 1945 dalam Pembangunan Hukum Ekonomi Indonesia," Jurnal Konstitusi, Vol. 9, No. 1, 2016, P. 49.

${ }^{4}$ Irfan Syauqi Beik, Op. Cit., P. 98.

${ }^{5}$ M. Dawam Rahardjo, "Menuju sistem perekonomian Indonesia," UNISIA, Vol. 32, No. 72, 2009, P. 13.
} 
3. The urgency to develop the concept of legal protection for creditors as a result of a power of attorney to impose a mortgage which is null and void is to ensure that the power of attorney imposing mortgage rights is not intentionally misused by the debtor. To ensure legal certainty from the power of attorney to impose mortgage rights, it is necessary to have certainty in terms of time and synchronization of regulations between the bank, notary and the National Land Agency, especially regarding the period from the drafting process to its approval to minimize the occurrence of time lapses of the SKMHT process that may harm the creditor. As a form of protection for creditors and to execute collaterals, the power of attorney to charge mortgage rights must first be registered and followed up with the making of APHT, then a certificate of mortgage having executive power and permanent legal force is issued as a manifestation of the principle of legal protection for creditors, thus it can be implemented perfectly.

\section{Recommendations}

1. To legislators, the novelty of SKMHT is important. The regulation regarding the SKMHT period based on Article 15 of the Mortgage Rights Law should be based on Article 1265 BW, namely absolute nullification because basically the time period has nothing to do with achievement.

2. Legislators are expected to revise laws related to SKMHT, namely by providing more certainty, clarity and legal protection for creditors regarding the uncertain SKMHT process, especially in the Land Office.

3. The National Land Agency of the Republic of Indonesia (BPNRI) is expected to pay attention to the general provisions for making authentic deeds before making regulations of authentic deeds; thus it will not cause different point of views on the SKMHT regulation, namely between Article 96 paragraph (1) of Regulation of the Head of the National Land Agency (Perkaban) number 8/2012 and Article 38 of the UUJN.

\section{References}

Abdul Rokhim dan MH SH, "Hak Informasi atas Kesehatan Bank," Jurnal Negara dan Keadilan, Vol. 6, No. 10

Agung Cahyo Kuncoro. Karakteristik Surat Kuasa Membebankan Hak Tanggungan Dalam Sistem Hukum Jaminan Di Indonesia. Jember: Dissertation, 2019

Ahmad Zulfikar, "Kekuatan Hukum Jangka Waktu Surat Kuasa Membebankan Hak Tanggungan Kredit Mikro pada Peraturan Menteri Agraria dan Tata Ruang/Kepala Badan Pertanahan Nasional Nomor 22 Tahun 2017," Wajah Hukum, Vol. 3, No. 2, 2019

Anwar Borahima Assaad \& Nurfaidah Said Ferry. "Kekuatan Hukum Surat Kuasa Membebankan Hak Tanggungan (SKMHT) Sebagai Dasar Pembebanan Hak Tanggungan Dalam Perjanjian Kredit” .

Anisa Kartika Sari, "Perlindungan Hukum Terhadap Kreditur Pemegang Hak Tanggungan Yang Tidak Didaftarkan Di Kantor Pertanahan,"

Budiono, Herlien. "Perikatan Bersyarat Dan Beberapa Permasalahannya" (2016) 2:1 VEJ 86.

Chandra Utama, "Mengukur tingkat kesehatan bank di Indonesia," Bina Ekonomi, Vol. 10, No. 1, 2006

Effendi Perangin-angin, 1987, Praktik Permohonan Hak Atas Tanah, Rajawali Press, Jakarta,

Elli Ruslina, "Makna Pasal 33 Undang-Undang Dasar 1945 dalam Pembangunan Hukum Ekonomi Indonesia," Jurnal Konstitusi, Vol. 9, No. 1, 2016

Fani Martiawan Kumara Putra. "Rekonstruksi Surat Kuasa Memasang Hipotek Dengan Pencantuman Klausula Kewajiban Pengikatan Sister Ship Manakala Jalur Pelayaran Dominan Lintas Batas Negara” (2018) 23:3 PERSP 183.

Ferry Assaad, Anwar Borahima, dan Nurfaidah Said, "Kekuatan Hukum Surat Kuasa Membebankan Hak Tanggungan (SKMHT) Sebagai Dasar Pembebanan Hak Tanggungan Dalam Perjanjian Kredit."

Fuat Rifai, Lucky Endrawati, Abdul Madjid, Analisis Yuridis Terhadap Ketentuan Surat Kuasa Membebankan Hak Tanggungan (SKMHT) Kredit Tertentu Sebagai Upaya Mewujudkan Keseimbangan Perlindungan Hukum Bagi Kreditur (BANK), Postgraduate Program, Faculty of Law, Universitas Brawijaya.

Hadi Wijaya, "Analisis Yuridis Terhadap Ketentuan Surat Kuasa Membebankan Hak Tanggungan (SKMHT) Kredit Tertentu Sebagai Upaya Mewujudkan Keseimbangan Perlindungan Hukum Bagi Kreditur (Bank)."

Ikatan Bankir Indonesia, 2016, Manajemen Kesehatan Bank Berbasis Risiko, Gramedia Pustaka Utama

Inche D P Sayuna. "Harmonisasi Dan Sinkronisasi Hukum Surat Kuasa Membebankan Hak Tanggungan (SKMHT) Ditinjau Dari Otentisitas Akta Menurut Undang-Undang Nomor 2 Tahun 2014 Tentang Perubahan Atas Undang-Undang Nomor 30 Tahun 2004 Tentang Jabatan Notaris" (2014)

I Putu Deny Wiryanta, I Ketut Mertha, dan I Made Puryatma, "Surat Kuasa Membebankan Hak Tanggungan (SKMHT) Dalam Perjanjian Kredit Perbankan Di Kota Denpasar," Acta Comitas, Oktober, 2016.

Irsyad Lubis. Bank dan Lembaga Keuangan (USUpress, 2010).

Iwan Triyuwono, "ANGELS: Sistem Penilaian tingkat kesehatan (TKS) bank syari'ah," Jurnal Akuntansi Multiparadigma, Vol. 2, No. 1, 2011

Maulana, Ayang Fristia. "Surat Kuasa Membebankan Hak Tanggungan Atas Tanah Negara (Studi Kasus PT X Di Kota Y)” (2018) 4:2 Jurdis 192. 
Miftahul Jannah, "Pelaksanaan Penandatanganan Akta Oleh Penerima Kuasa Dalam Akta Surat Kuasa Membebankan Hak Tanggungan (Skmht) Yang Dibuat Oleh Notaris."

M. Khoidin. Dimensi Hukum Hak Tanggungan Atas Tanah Cet.1. Yogykarta: Laksbang, 2005

M. Dawam Rahardjo, "Evaluasi dan Dampak Amandemen UUD 1945 terhadap Perekonomian di Indonesia," UNISIA, No. 49, 2016 Taufiqurrohman Syahuri, "Politik Hukum Perekonomian Berdasarkan Pasal 33 UUD 1945," Jurnal Konstitusi, Vol. 9, No. 2, 2016,

M. Dawam Rahardjo, "Menuju sistem perekonomian Indonesia," UNISIA, Vol. 32, No. 72, 2009

Muhammad Iqbal, "Kajian Yuridis terhadap Surat Kuasa Membebankan Hak Tanggungan Kedua (II) dan Berikutnya sebagai Perpanjangan Surat Kuasa Membebankan Hak Tanggungan Pertama (I) yang Telah Berakhir Jangka Waktu," PREMISE LAW JURNAL, Vol. 15, 2016

Padang, Paulus Tiku Taru \& Olivia Maria Dotulong. “Akibat Hukum Surat Kuasa Membebankan Hak Tanggungan Yang Tidak Dilaksanakan Sampai Tenggang Waktu Berakhir” (2017) 7:1 Jurnal Pemberdayaan Hukum.

Permadi Gandapraja, 2004, Dasar dan Prinsip Pengawasan Bank, Gramedia Pustaka Utama

Peter Mahmud Marzuki, Penelitian Hukum, Jakarta: Prenada Media, 2005

Sastradinata, Dhevi Nayasari. "Tinjauan Yuridis Terhadap Surat Kuasa Membebankan Hak Tanggungan (SKMHT) Sebagai Media Pengikatan Jaminan Pada Proses Kredit Take Over Pada Perusahan Perbankan” (2017) 5:1 JIFH 39

Siti Malikhatun Badriyah, "Perlindungan Hukum Bagi Kreditor dalam Penggunaan Base Transceifer Station (Bts) sebagai Objek Jaminan Fidusia dalam Perjanjian Kredit,” Media Hukum, Vol. 22, No. 2, 2016

Suteki dan Galang Taufani. Metodologi Penelitian Hukum (Filsafat, Teori dan Praktik). Depok: RajaGrafindo Persada, 2018

Thamrin Abdullah, Bank dan Lembaga keuangan" (2014)

Try Widiyono. Agunan Kredit Dalam Finansial Engineering :Panduan Bagi Analisis Kredit dan Perbankan. Bogor: Ghalia Indonesia, 2009

Widjaja, Hadi Saputro. "Untuk Memenuhi Sebagai Persyaratan Mencapai Derajat Sarjana S-2 Magister Kenotariatan" 